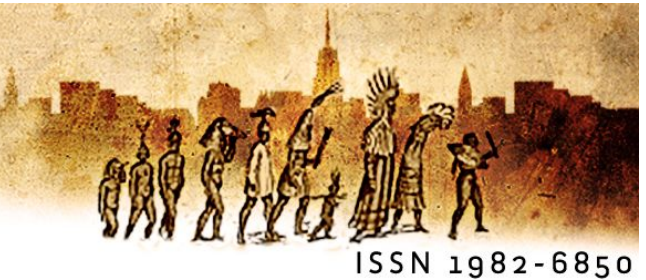

\title{
Beyond words: pornography and style translated in Charles Bukowski's two poems from Love is a Dog from Hell
}

\author{
Luana Ferreira de Freitasi (UFC) \\ Rebecca de Lima Correiaii (UFC) \\ It got bigger. Just before I was ready \\ I stopped, I held it at the bottom \\ stretching it, \\ the head throbbed \\ purple and shiny. \\ Charles Bukowski ( Love is a Dog from Hell, 1977, p.69)
}

\begin{abstract}
This paper aims to analyze aspects of the translation of two poems from the book Love is a Dog from Hell (1977) by Charles Bukowski, more specifically, to examine whether the pornography and the author's style survive the Brazilian translation by Pedro Gonzaga entitled $O$ Amor é um cão dos Diabos (2011). The poems under investigation are "The 6 foot goddess" and "One of the hottest". The figures of speech used by the author, namely hypotyposis, climax, alliteration, simile and metaphor are the basis for the analysis, which will take place by means of comparison between fragments in English and Brazilian Portuguese, in Gonzaga's translation.

Keywords: Charles Bukowski; poetry; pornography; translation; figures of speech.
\end{abstract}

Resumo: O objetivo deste artigo é analisar aspectos da tradução de dois poemas do livro Love is a Dog from Hell (1977) de Charles Bukowski, mais especificamente, examinar se a pornografia e o estilo do autor sobrevivem à tradução brasileira de Pedro Gonzaga intitulada O Amor é um Cão dos Diabos (2011). Os poemas investigados são "A deusa de um metro e oitenta" e "Uma das mais quentes". As figuras de linguagem usadas pelo autor, a saber, hipotipose, clímax, aliteração, símile e metáfora servem de base para a análise, que se dará por meio de cotejo entre fragmentos em inglês e em português brasileiro, na tradução de Gonzaga.

Palavras-chave: Charles Bukowski; poesia; pornografia; tradução; figuras de linguagem. 


\section{Introduction}

Regarding literature, Culler (1997, p. 9) alerts, "for one thing, literature is about sex; literature is one of the places where this idea of sex is constructed, where we find promoted the idea that people's deepest identities are tied to the kind of desire they feel for another human being." However, there is a general assumption that pornographic literature is not literary enough. Some conservative trends had banished many sorts of works labelling a new form of literature to the shadowy world. Nevertheless, on the literary field it seems unwise to limit the possibilities of the literary range, mainly, because literature is inorganic, and nothing should set boundaries in it.

Another way of defining literature is to limit it to "great books," books which, whatever their subject, are "notable for literary form or expression." Here the criterion is either aesthetic worth alone or aesthetic worth in combination with general intellectual distinction. Within lyric poetry, drama, and fiction, the greatest works are selected on aesthetic grounds; other books are picked for their reputation or intellectual eminence together with aesthetic value of a rather narrow kind: style, composition, general force of presentation are the usual characteristics singled out. This is a common way of distinguishing or speaking of literature. By saying that "this is not literature," we express such a value judgment. (WELLEK; WARREN, 1949, p.10).

Contradicting the aforementioned belief, this essay is an invitation to revisit Charles Bukowski's marginal, non-academic, explicit and raw writing, under a different perspective through the recognition of the aesthetic value of his writings and the way it survives the translation process itself, overcoming its obstacles.

\section{Eroticism and pornography}

The conceptualization of eroticism and pornography might vary from time to time and place to place, depending on the timeline history of literature. Alexandrian (1991, p. 11) clarifies that for a long time the antiquity erotic literature was a genre as any other and it was really appreciated by society.

Not always has erotic literature been depreciated, obligating its authors to anonymity and its works to illegal diffusion. Among ancient Greeks and Romans, the best authors revealed themselves without fake shame during daylight. The erotic literature was simply not included in the noble genre 
that included Tragedy and Epic; its domain was the familiar genre, comedy, tales, elegiac poetry; satire or epigrammatic. ${ }^{1}$

The Obscene Effect by Moraes (2003, p.129) points out to an important detail upon the pornographic ideological construction through history. In Renaissance, the presence of pornography became more intense and it was characterized by the diffusion of images and obscene vocabularies which caused moral injury because of the explicit representation of sex. Is there a difference between eroticism and pornography? The reason behind the great misunderstanding between pornography and erotica is the sense of aesthetic. In fact according to some authors, both terms are complementary. Regarding the erotic aesthetic, it is organized by beauty patterns. Despite the belief that pornography tends to reveal everything and eroticism tends to give a blurred reality, Moraes argues explicitly that there is a difficulty to establish a difference between both terms. Based on this presumption, we can assume that there are no boundaries separating them. We propose a difference between pornography and obscenity, the latter being connected with vulgar and offensive vocabularies and appealing to moral transgression. From now on this essay will use pornography as a key term to the development of this work, mostly, because pornography is directly related to the presence of portraits.

Hunt (1999, p. 13-14) reveals that in 1857 the word pornography appeared for the first time in the Oxford English Dictionary, and its variations - pornographer and pornographic - are from the same period. These entries had arisen just before in France. According to Trésor de la langue fraçaise, the word pornographe appeared in texts about prostitution, while pornographique, pornographe and pornographie in writings about obscene images. In this case, I am considering that the words presented in Bukowski's text can easily assume the sign itself, giving more than a representation, those words can easily replace images.

To complement the abstraction upon the concept of pornography, Alexandrian (1991, p. 20) in his book História da literatura erótica, brings a historical overview of the word pornography. Through it we have an interesting perspective about the origins of the term:

\footnotetext{
1 "Nem sempre a literatura erótica foi depreciada, obrigando os seus autores ao anonimato e as suas obras à difusão clandestina. Entre os gregos e os romanos da antiguidade exprimia-se à luz do dia; os melhores autores sem falsa vergonha. Simplesmente, não era incluída no género nobre que compreendia a tragédia e a epopeia; o seu domínio era o do género familiar, o da comédia, do conto, da poesia elegíaca, satírica ou epigramática". (p. 11)
} 
Many people use the word pornography without knowing what it means. It comes from pornê (prostituted) and initially referred to written narrative of the practices of prostitution. Before Lucian [of Samosata], it was employed as a technical term for erotic paintings of Parrhasius, because his models were public women. Gradually, everything that described sexual relations without love, compatible with the relations that prostitutes had with their clients, started being classified as pornographic. ${ }^{2}$

Considering Bukowski's writings we can observe that he is socially defying the portrait of pornography based on his experiences. In his literature a sort of self-assertion can be seen initially, a pride of exposing his behavior as man, almost like teenagers do. "The artist," says Freud," is originally a man who turns from reality because he cannot come to terms with the demand for the renunciation of instinctual satisfaction as it is first made, and who then in phantasy-life allows full play to his erotic and ambitious wishes" (WARREN, WELLEK, 1949, p. 76). Bukowski has the necessity of self-expression, in a confessional tone. "The literary work of Bukowski cannot be studied without the understanding that his personal view of sexuality is, no doubt, the most compelling formative topic of his literature" (SHAW, 1997, p.75).

Allying some of these concepts by Wellek and Warren (1949), we could put together these pieces of the puzzle called poetry. It may be relevant to use the following fragment to justify Bukowski's marginal writing and his literary choices, his life justifying his literary works:

Biography also accumulates the materials for other questions of literary history such as the reading of the poet, his personal associations with literary men, his travels, the landscape and cities he saw and lived in: all of them questions which may throw light on literary history, i.e., the tradition in which he poet was placed, the influences by which he was shaped, then materials on which he drew. (WELLEK; WARREN, p.73)

Some authors that earned recognition due to their works had their specific ways of inspiration. For instance, Schiller kept rotten apples in his work-desk; Balzac wrote dressed

\footnotetext{
2 "Muitos empregam a palavra pornografia sem saberem o que significa. Vem de pornê (prostituída) e designava a princípio um escrito que narrava as práticas da prostituição. Antes de Luciano [de Samosata], empregava-se como termo técnico de pintura para definir quadros eróticos de Parrásio, porque os seus modelos eram mulheres públicas. Pouco a pouco, começou-se a classificar de pornográfico tudo o que descrevia as reações sexuais efectuadas sem amor, comparáveis às de uma prostituta com o seu cliente."
} 
in the robes of a monk (WELLEK; WARREN, 2003, p. 81). It was not different with Bukowski, the difference is that he had the necessity to be drunk on the most degraded level to do it. Putting together all these literary themes, we have the right human characteristics and a disturbed life that made him what he truly is in the modern field of literature.

\section{The poet}

The poet and author Henry Charles Bukowski was born in Andernach, Germany, in 1920. However, he lived his whole life in The United States, in Los Angeles, where he built up his career as a writer. The fact that some of his books were translated into at least fifteen languages, including Brazilian Portuguese, and even in Japanese, indicates international recognition of his work and its relevance not only to North-American contemporary literature, but to literature in general.

Bukowski landed in Brazil for the first time through Brasiliense publisher, which was responsible for publishing his first novel, Post Office, translated as Cartas na Rua in 1983 by Alberto Alexandre Martins and Marilene Felinto.

There are those who know me, in Brazil. Those who have never heard my name do not know what they are missing. I bring with me all curse routes, I hate the whole world. I contempt it as a bunch of shit, I know that I am not accustomed to writing to family newspapers (BUKOWSKI, p. 12, 1983). ${ }^{3}$

With this in mind, the present work intends to analyze how the translator dealt with the author's provocative lexical choices and the pornography permeated in his writings. Bukowski was a tardy writer, but this fact did not prevent his success. "Throughout the late 1960's and into the early 1970's Bukowski additionally expanded his reader base by being published as a writer of erotica in numerous national pornography magazines" (SHAW, 1997, p. 74).

For this research, the two specific poems aforementioned have been chosen. They present some characteristics in common: the presence of obscene words that characterize his texts as a signature, the way the author describes sex, his relationship with women, and his lexical and stylistic choices. These words were identified, mainly, because of the heavy

\footnotetext{
3 "Há quem não me conheça, no Brasil. Os que nunca ouviram falar de meu nome não sabem o que estão perdendo. Trago comigo todas as rotas da maldição, detesto todo o mundo, desprezando-o como um monte de bosta. Sei que não sou polido, mas não é minha culpa. Não costumo escrever para jornais de família."
} 
sexual and vulgar connotation found in them. Those obscene words allowed in his writing are not marking just the pornographic style, more than that, they are building the presence of the body itself. Those vocabularies are purely fetishist, even more, they are confessing the intensity of desire through our imagination. The visual appeal is perceptive in both poems. Through his written work, Bukowski can describe his ideas in a sensorial way that deeply involves the reader. Taking into consideration that pornography is a construction based on visual aids, we would like to highlight both sensorial and visual aspects in Bukowski's style. According to Walsh (2008, p. 1):

On one hand, the style and structure of his writing seems primitive, raw, unformed, undisciplined; moreover, the content raises serious issues, legitimate concerns about what is appropriate as subject matter to literary expression. There are elements of misanthropy, misogyny, and even sexual perversion that must be addressed.

\section{Book and poems}

For the reasons pointed out so far, his book Love is a Dog from Hell was chosen. It was first published in 1977 by HarperCollins publishers. It is a poetry collection concerning Bukowski's experiences with the limits of love, heartbreaks, women and, mainly, alcohol. It is raw and at the same time lyrical. The book is divided into four chapters, totaling around one hundred sixty poems with many themes. Its Brazilian translation was published by L\&PM Pocket (2007) entitled O Amor é um Cão dos Diabos by Pedro Gonzaga and follows the same characteristics. Moreover, this paper intends to use the translated poems as the primary source of investigation.

According to L\&PM website, they are a publisher specialized in pocket books, in the market since 1974. The publisher emerged from a simple and practical idea - Ivan Pinheiro and Paulo Almeida tried to survive an economic crisis by bringing the pocket books idea from Europe. Through this action pocket books in Brazil were spread and popularly commercialized, and L\&PM Pocket became one of the most important pocket books publishers in Brazil. The books are sold at a low cost, 55\% less than the other versions, which makes them appealing to the readership. 
This work also proposes to reflect on the role of the translator from the perspective of his lexical choices. It is important to understand the pivotal role of how some lexical choices can modify the final result. Is it appropriate to soften the text a little bit and change the first version due to the words that Bukowski had used?

Considering one of the important pieces to this puzzle, Pedro Gonzaga, besides being a translator, is a musician, writer and professor. He was born in Porto Alegre and studied at Universidade Federal do Rio Grande do Sul. Through L\&PM Pocket he has translated at least six of Bukowski's books, and one of them is Love is a Dog from Hell.

\section{Poems analyzed}

We will look into Bukowski's poems looking for specific features of his writing and how his translator into Brazilian Portuguese dealt with these singularities.

\subsection{The 6 Foot Goddess}

the 6 foot goddess

I yank her head back by the hair,

I'm real macho,

I suck on her upper lip

her cunt

her soul

I mount her and tell her,

"I'm going to shoot white hot juice into you. I didn't fly all the way to Galveston to play

chess."

later we lay locked like human vines

my left arm under her pillow

my right arm over her side

I grip both of her hands,

and my chest

belly

balls

cock

tangle into her

and through us

in the dark

pass rays

back and forth a deusa de um metro e oitenta

puxo-lhe a cabeça para trás pelos cabelos, sou macho de verdade, chupo-Ihe o lábio superior

sua xoxota

sua alma

monto sobre ela e lhe digo,

"vou lançar suco quente e branco

dentro de você. não voei desde

Galveston para jogar

xadrez".

depois nos deitamos enlaçados como vinhas humanas meu braço esquerdo debaixo de seu travesseiro meu braço direito sobre o lado de seu corpo aferro-me às suas mãos,

e meu peito

barriga

bolas

pau

enroscam-se nela

e através de nós

no escuro

passam raios

pra lá e pra cá 
back and forth

until I fall away

and we sleep pra lá e pra cá

até que eu desfaleça

e nós durmamos.

The first aspect that called our attention was Bukowski's use of language, for it is almost a character, and its strong presence can be seen in the images he creates through it. The poem invites us to be part of one of the most important aspects of his poetry, a cinematographic style of writing. The solid visual appeal in Bukowski makes language turn into shots, such as in the above stanzas.

Bukowski seems to use language and to create images in his poetry in a conscious way through different figures of speech, manipulating his readers through his confessional tone. In "the 6 foot goddess", we analysed four figures of speech presented in his text: climax, hypotyposis, simile and alliteration. Observing the third, fourth and fifth lines of the poem:

\author{
I suck on her upper lip \\ her cunt \\ her soul
}

We have an example of climax, starting physically by sucking her mouth, her vagina and finally spiritually, by sucking her soul. We have a movement in the scene, a series of words in an increasing order of magnitude. Although it is common for Bukowski to use vulgar register, as cunt for instance, some stylistic choices emerge from his writings. Highlighting these two different words used by Bukowski, cunt and soul, according to Oxford English Dictionary cunt is known as a very offensive word. Moore (2012) indicates "cunt was referred to by censor Hope Hewitt in the mid-196o's as 'the Lawrentian word' and is still taboo in many kinds of publications". Thus, cunt is pointed out as an obscene word, about the obscene registers Hunt (1999, p. 39) says,

The obscene word played on the contrast between different social registers of language - crude and elegant, lower and upper class, masculine and feminine - in order to achieve its effect. To enact social transgression and a kind of hyperrealism, obscene language fetishizes certain words related to sex; the obscene word substitutes for the body part in question but, in the process, acquires the status of a fetish. 
Through the word soul, the author achieves exactly the mentioned result. He used two words with different categories. However, these words are complementing one another. The word soul comes impacting and suggesting an elevation of the sexual relation sacralizing it, Bukowski also appealed to a metaphysic relation between the characters in the verse.

Pedro Gonzaga appealed many times to the use of enclisis in his translation, such as in "aferro-me às suas mãos" or "enroscam-se nela". Enclisis is not used in oral Brazilian Portuguese, and by using it, Gonzaga distances his Brazilian translation from Bukowski's style of writing and the author's clear choice for oral register.

Observing the aforementioned stanzas of the poem, we have noticed a recurrent characteristic, one of the greatest features in Bukowski's work. The author uses a resource through his writing that gives us a sensation that we are part of the text. The word projected by Bukowski suggests us images appealing to our sensorial perception there is nothing vague or foggy about his verses. He wants his reader to take part of the action; he wants to appeal to voyeurism. According to Paganine (2011, p. 307-309),

Such feature is known as hypotyposis, a figure of speech whose rhetorical effect, it is argued, is able to paint the facts of which we speak as if what is said was, in fact, before our eyes. (...) In hypotyposis, more than words, what counts are the images they suggest.(...) Perhaps this quality of demanding from the reader an evocative visual involvement from the words has the consequence of approaching the reader of the narrative, giving the reader the feeling of observing, of watching the drama of the characters through successive frames. ${ }^{4}$

Therefore, hypotyposis is responsible to give a vivid description of an action, event or scene using the illusion of reality projecting real life through the text. This aspect can be better observed in the next stanza:

I yank her head back by the hair,

I'm real macho,

I suck on her upper lip

\footnotetext{
4 "(...) Tal recurso é conhecido como hipotipose, uma figura de linguagem cujo efeito retórico, afirma-se, é capaz de "pintar os fatos dos quais se fala como se o que se diz estivesse, de fato, diante dos olhos (...) $\mathrm{Na}$ hipotipose, mais que as palavras, o que conta são as imagens que elas sugerem. (...) Talvez essa qualidade de demandar do leitor um envolvimento evocativo e sensorialmente visual a partir das palavras tenha por consequência aproximar o leitor da história, dando-lhe a sensação de estar observando e assistindo ao drama das personagens através de quadros sucessivos."
} 


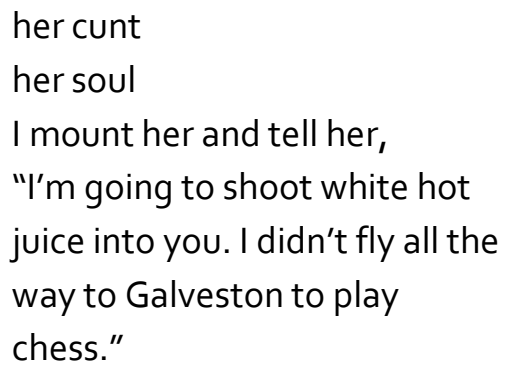

There are two figures of speech in the second stanza too, one of them is alliteration and the other is simile, both are presented in the same verse:

later we lay locked like human vines

After the sexual moment, they were intertwined like vines. Alliteration was achieved through using successive words with the same consonant L. Simile suggests a comparison between two objects. In the line above, the speaker indicates by the connecting word "like" two objects comparing them.

Considering the Brazilian Portuguese translation made by Pedro Gonzaga, in a general overview it follows some similarities. Concerning translation of the aforementioned lines, the translator should have selected a word with the same vulgar register to reach what Bukowski said with "cunt". Unfortunately, by using the word "xoxota" the climax did not have the same impact. In alliteration Gonzaga used "depois nos deitamos enlaçados como vinhas humanas". He chose the letter $D$ to replace the effect of $L$ achieving as close as possible a similar result. The simile was preserved in Pedro Gonzaga's translation: "enlaçados como vinhas humanas".

\subsection{One of the Hottest}

one of the hottest

she wore a platinum blond wig and her face was rouged and powdered and she put the lipstick on making a huge painted mouth and her neck was wrinkled but she still had the ass of a young girl and the legs were good. she wore blue panties and I got them off uma das mais quentes

ela usava uma peruca de um loiro platinado e tinha a face carregada de rouge e pó e não economizava no batom traçando uma enorme boca pintada e seu pescoço era coberto de rugas mas ainda tinha o rabo de uma garota e as pernas eram boas.

ela usava calcinhas azuis que eu baixei e 
raised her dress, and with the TV flickering I took her standing up.

as we struggled around the room

(I'm fucking the grave, I thought, I'm

bringing the dead back to life, marvelous

so marvelous

like eating cold olives at 3 a.m.

with half the town on fire)

I came.

You boys can keep your virgins

Give me hot old women in high heels

with asses that forgot to get old.

of course, you leave afterwards

or get very drunk

which is the same

thing

we drank wine for hours and watched tv and when we went to bed

to sleep it off

she left her teeth in all

night long. ergui seu vestido, e à luz bruxuleante da TV tomei-a de pé.

enquanto nos digladiávamos ao redor do quarto

(estou fodendo uma cova, pensei,

trazendo os mortos de volta à vida, maravilhoso

tão maravilhoso

como comer azeitonas geladas às 3 da manhã

com metade da cidade em chamas)

gozei.

vocês podem ficar com suas virgens, rapazes

deem-me velhas gostosas no alto de seus saltos

com rabos que esqueceram de envelhecer.

claro, você tem que dar o fora depois

ou ficar muito bêbado

o que é a mesma

coisa.

bebemos vinho por horas e assistimos tevê e quando fomos pra cama

para dormir

ela não tirou os dentes da boca

a noite toda.

The women in these two poems have no subjectivity, no voice, and no desire. They have been alienated from the language game, and they are no subjects of their desire. The speaker starts describing an old lady's physical appearance comparing her ass with an ass of a young girl. In the middle of his description what called our attention was the fact that when he had a sexual relation with her, the speaker thought:

"I'm fucking the grave, I thought,

I'm bringing the dead back to life".

In this verse, the speaker used a complex metaphor to her sexual organ comparing it to a grave, at the same time to death. Meener (2008, p. 30) says "the other extreme approach, plentifully exhibited in Bukowski's work, is concerned with the association of death and sex. Sex and death have always been related to each other like the life-bringer, lust-giver Eros and its shadowy, eerie counterpart Thanatos". Bataille (1957, p. 35) said, "Eroticism is the approval of life even into death." ${ }^{5}$ The above poem was constructed

\footnotetext{
50 erotismo é a aprovação da vida até na morte.
} 
suggesting opposite ideas: old age and youth, life and death, Eros and Thanatos. The speaker suggests that he is having sex with death itself. On the other hand, the old lady is rejuvenated by sex, by pleasure. In this poem, sex is salvation. Despite all his vulgar lexical choices the sexual relation emerges to save them from what they are. In the last stanza, she is denying her advanced age by keeping her teeth in her mouth.

she left her teeth in all

night long.

According to Online Etylomogy dictionary, obscene (adj.) comes from 1590s, "offensive to the senses, or to taste and refinement," from Middle French obscéne. Therefore, in other words, something is clear which offends morality by means of sexual representation. Bukowski puts death in the same perspective as life. He used a metaphor, always contrasting two complex images. According to Moraes (2014, p. 311), to eroticism it does not matter the reason of sexual desire, it deals with violating the integrity of bodies, desecrating identities to achieve chaos. Eroticism means a fusion, a suppression of limits. Through his lexical choices, Bukowski surpasses social limits, demonstrating moral transgression.

In Gonzaga's translation we can notice some interesting lexical choices. These choices present a different perspective from what Bukowski said in his verses. Comparing the fragments:

she wore blue panties and I got them off raised her dress, and with the TV flickering I took her standing up.

as we struggled around the room ela usava calcinhas azuis que eu baixei e ergui seu vestido, è̀ luz bruxuleante da TV tomei-a de pé. enquanto nos digladiávamos ao redor do quarto

Sometimes Gonzaga seems to stick to the source text in his translation, neglecting the usage in Brazilian Portuguese, as in "calcinhas azuis" for "blue panties", since in Brazil, the word calcinnha in used in singular. Once more the use of enclisis "tomei-a de pé" distances the Brazilian translation from the source text. On the other hand, his "à luz bruxuleante da TV" instead of the most obvious "com a TV brilhante" conveys a more poetic effect to his Brazilian translation. 


\section{On literary translation}

Translation is a decision-making process as well as a communicative process. It is a decision because there is a range of alternative words from which the translator needs to choose for the best result. "Every interpretation has the structure of problem solving: the interpreter has to choose from a class of possible meaning of the word or motif, from different conceptions of a character, of style, or of the author's philosophical views." It is a communication process because the aim is to convey the ideas and/or emotions of a piece of art. "The choice of a lexical unit is governed by such a system of conscious or unconscious. They are both objective, dependent on the linguistic material and subjective, of which the most important are the structure of the translator's memory, his aesthetic standards, etc" (LEVÝ, 2000 p. 156). Levý (2000, p. 156):

Translation theory tends to be normative, to instruct translators on the OPTIMAL solution; actual translation words, however, is pragmatic, the translator resolves for that one of the possible solutions which promises a maximum of effect with a minimum of effort. That is to say, he intuitively resolves for the so-called MINIMAX STRATEGY.

Some scholars argue that translation is just the appropriate interpretation of a unit code and that equivalence is impossible (BASSNETT, 2002, p. 39). However, poetry has been translated at least since the Romans with varied outcomes, and it is through translation that humankind has got in touch with all kinds of texts from different civilizations and times. Thus defining translation as a search for equivalents and believing that translation of poetry is impossible is denying the very history of literature.

Considering Bassnett (2000, p. 34), we can observe that each word has a different register which means that some words cannot be replaced by others as the linguistic registry will not achieve the same lexical result. If we put those words side by side, they do not have the same emblematic significance because Gonzaga's translation changes the core of the word. The word needs translation, of course, but not so mechanically. In translating Bukowski we must be aware of the vocabulary used, mainly because in this specific context, it comes from the streets, the author expresses himself through oral register. The function of a text also needs to be considered, since we are not speaking in simple word replacement. The words Bukowski used convey strong essence and have great relevance to the text, apparently. If we consider Pedro Gonzaga's case in the book O Amor é um Cão dos Diabos, 
we have other possible choices that could fit better for the final result, Gonzaga could have used a register closer to that of Bukowski's.

Considering the inevitable loss of information in a translation, it can be said that they are not much different from the loss in an intralingual communication process. As in all communication processes some kind of loss of information occurs, it is natural that it happens in translations as well. "It is true, we could add at the same time that a loss of information occurs when communication is established, it can be verified also a process of creation of some new information. Then, the loss would be compensated"6 (ANTUNES, 1991, p. 2).

Words are more than small parts or units of a language. Together, they are a code, and words have their own behavior in language, and more importantly in literature. Each obscene word in the poems analysis has relative importance to the whole of Bukowski's writings. This is the reason why translators need to be aware of their role as cross-cultures mediators.

According to Susan Bassnett (2002, p. 31), the translator needs to consider five relevant facts when translating in order to determine which expression to use: One: The untranslatability, on the linguistic level, from original phrase to the target language. Two: The absence of a social convention in the target language. Three: The range of existent expressions in the target language, answering the class, statute, age, gender of speaker. Four: Consider the phrase signification in its particular context, a moment of high tension in dramatic texts. Five: The need to replace, in the target language, the invariant core of the phrase in the source language in both reference systems (the particular system of the text and the cultural system in which the text appears.) This means that the translator is required to follow every step, removing his/her subjectivity, and making translation something close to a punishment. "The translator cannot be the author of the source text, but as the author of translated text has a clear moral responsibility to the readers of the target language text" (BASSNETT, 2002, p.49).

Translation involves far more than replacement of lexical and grammatical items between languages and, as can be seen in the translation of idioms and metaphors, the process may involve discarding the basic linguistic

\footnotetext{
${ }^{6}$ É bem verdade, poderíamos acrescentar, que ao mesmo tempo em que se dá perda de informação quando se estabelece uma comunicação, verifica-se também o processo de criação de informação nova. E aí as perdas estariam compensadas.
} 
elements of the source language text so as to achieve (...) 'expressive identity' between the source language and target language texts. But once the translator moves away from close linguistic equivalence, the problems of determining the exact nature of the level of equivalence aimed for begin to emerge (BASSNETT, 2002, p. 34).

We believe that translation is a clear decision process, sometimes the translator comes to a better decision, sometimes he does not, but the translator needs to consider all his linguistic possibilities. Bassnett (2002, p. 45) points out that it seems, therefore, unacceptable to argue that the translator's task is translating and not interpreting. How could it be done as separate tasks?

\section{Conclusion}

All considered, it is necessary to understand the difficult role of being a translator and the great responsibility it encompasses. It is important to mention that translation needs to consider many issues, but the most important one is literature itself. Another aspect is the author's lexical choices. If we have a great range of choices all of them need to be considered, trying to aim at legibility. Translation is a process involving source and target languages, source and target cultures, knowledge about the author's life, and the theme itself. Through the analysis of Gonzaga's lexical choices, we could not only learn more about Bukowski's style and texts, but also conceive what the translation process involves in all its complexities. In the case of this particular translation, we had the opportunity to understand that there is no right or wrong, but nuances of register that could potentially jeopardize the effect of a piece of work. 
Appendix

"THE 6 FOOT GODDESS" AND PEDRO GONZAGA'S VERSION "A DEUSA DE UM METRO E OITENTA".

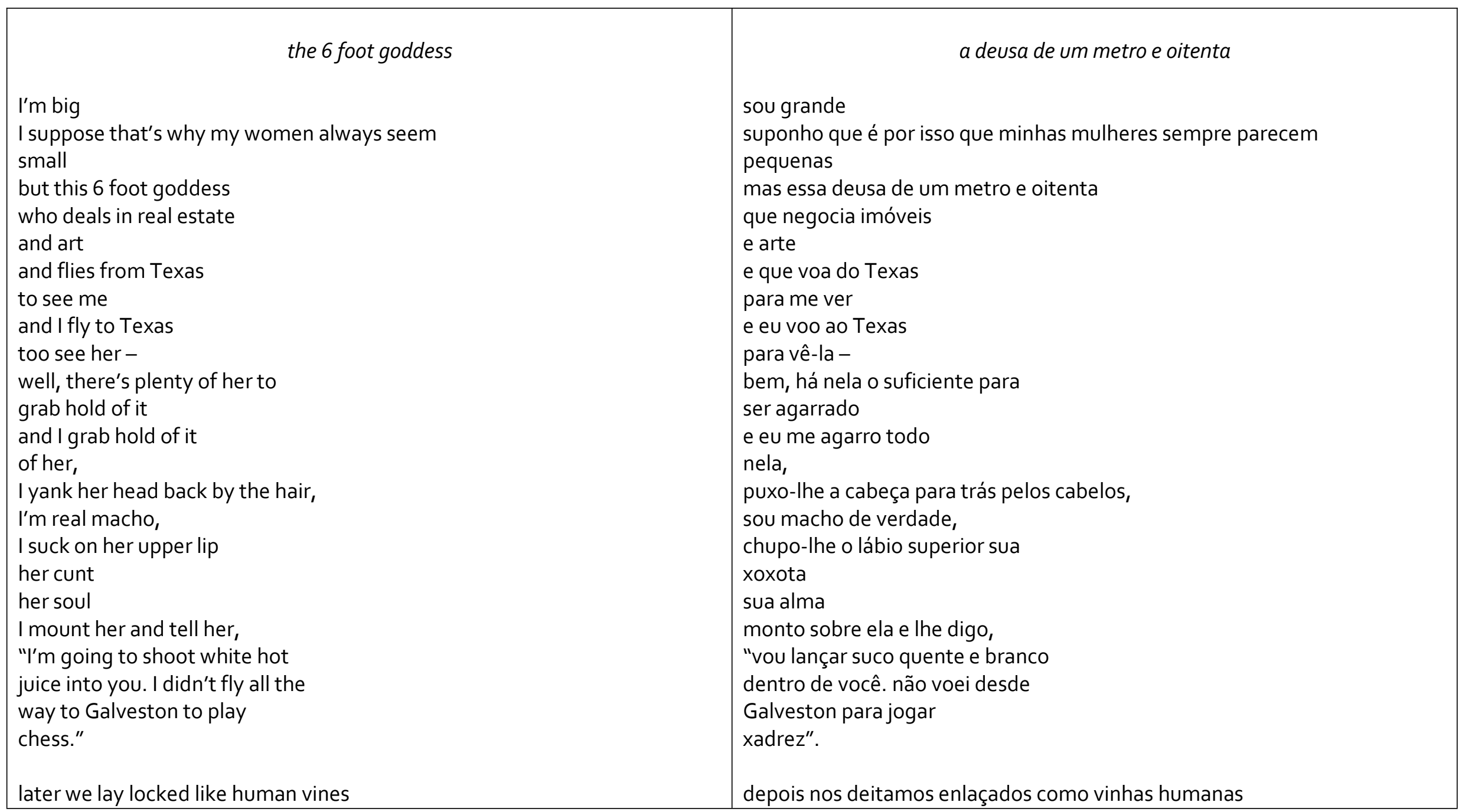


My left arm under her pillow

My right arm over her side

I grip both of her hands,

and my chest

belly

balls

cock

tangle into her

and through us

in the dark

pass rays

back and forth

back and forth

until I fall away

and we sleep

she's wild

but kind

my 6 foot goddess

makes me laugh

the laughter of the mutilated

who still need

love,

and her blessed eyes

run deep into her head

like mountain springs

far in

and

cool and good.

she has saved me

from everything that is

not here. meu braço esquerdo debaixo de seu travesseiro

meu braço direito sobre o lado de seu corpo

aferro-me às suas mãos,

e meu peito

barriga

bolas

pau

enroscam-se nela

e através de nós

no escuro

passam raios

pra lá e pra cá

pra lá e pra cá

até que eu desfaleça

e nós durmamos.

ela é selvagem

mas dócil

minha deusa de um metro e oitenta

faz-me rir

a risada do mutilado

que ainda precisa de

amor,

e seus olhos abençoados

fluem para o fundo de sua cabeça

como nascentes na montanha

ao longe

nascentes

frescas e boas.

ela me resguardou

de tudo o que não está

aqui. 
"ONE OF THE HOTTEST" AND PEDRO GONZAGA'S VERSION "UMA DAS MAIS OUENTES".

\section{uma das mais quentes}

she wore a platinum blond wig

and her face was rouged and powdered

and she put the lipstick on

making a huge painted mouth

and her neck was wrinkled

but she still had the ass of a young girl

and the legs were good.

she wore blue panties and I got them off

raised her dress, and with the TV flickering

I took her standing up.

as we struggled around the room

(I'm fucking the grave, I thought, I'm

bringing the dead back to life, marvelous

so marvelous

like eating cold olives at 3 a.m.

with half the town on fire)

I came.

You boys can keep your virgins

Give me hot old women in high heels

with asses that forgot to get old.

of course, you leave afterwards

or get very drunk

which is the same

\section{one of the hottest}

ela usava uma peruca de um loiro platinado

e tinha a face carregada de rouge e pó

e não economizava no batom

traçando uma enorme boca pintada

e seu pescoço era coberto de rugas

mas ainda tinha o rabo de uma garota

e as pernas eram boas.

ela usava calcinhas azuis que eu baixei e

ergui seu vestido, è luz bruxuleante da TV

tomei-a de pé.

enquanto nos digladiávamos ao redor do quarto

(estou fodendo uma cova, pensei,

trazendo os mortos de volta à vida, maravilhoso

tão maravilhoso

como comer azeitonas geladas às 3 da manhã

com metade da cidade em chamas)

gozei.

vocês podem ficar com suas virgens, rapazes

deem-me velhas gostosas no alto de seus saltos

com rabos que esqueceram de envelhecer.

claro, você tem que dar o fora depois

ou ficar muito bêbado

o que é a mesma 


\section{thing}

we drank wine for hours and watched tv and when we went to bed

to sleep it off

she left her teeth in all

night long. coisa.

bebemos vinho por horas e assistimos tevê

e quando fomos pra cama

para dormir

ela não tirou os dentes da boca

a noite toda. 


\section{References}

ALEXANDRIAN. História da literatura erótica. Lisboa: Livros do Brasil, 1991.

ANTUNES, Benedito. Notas sobre a tradução literária. Alfa, São Paulo, v. 35, p. 1-10, 1991.

BASSNETT, Susan. Translation studies. New York: Routledge Taylor \& Francis Group, 2005.

BATAILLE, Georges. O erotismo. [Tradução: Fernando Scheibe]. Belo Horizonte: Autêntica Editora, 2014.

BUKOWSKI, C. Um vagabundo celestial. [2 de outubro, 1983]. São Paulo: Revista da Folha de São Paulo. Entrevista concedida a Antonio Gonçalves Filho.

BUKOWSKI, Charles. Love is a dog from hell. New York: HarperCollins, 2003.

O amor é um cão dos diabos. [Tradução: Pedro Conzaga]. Porto Alegre:

L\&PM Pocket, 2011.

CULLER, Jonathan. Literary Theory: A very short introduction. New York: Oxford, 1997.

HUNT, Lynn. A invenção da pornografia. [Tradução: Carlos Szlak] São Paulo: Hendra, 1999.

LEVÝ, Jirí. Translation as a decision process. In: VENUTI, Lawrence. The translation Studies Reader. London and New York: Routledge, 2000.

MEENER, Michal. Representations of the Female in the Work of Charles Bukowski. 48 p. Univerzita Karlova - Filozoficka Fakulta, República Tcheca, 2008.

MILLER, Henry. Obscenity and the Law of Reflection. The Confession Press, 1950.

MOODY, Lori. Charles Bukowski leaves a controversial legacy. Los Angeles Daily News, 2004. Found in: <http://articles.chicagotribune.com/1994-03-

16/features/9403160104_1_publisher-john-martin-charles-bukowski-john-rechy>.

MOORE, Nicolle. The Censor's Library. Australia: University of Queensland Press, 2012.

MORAES, Eliane Robert. O efeito obsceno. Cadernos Pagu, São Paulo, n. 20, 2003. 
PAGANINE, Carolina. Três contos de Thomas Hardy: tradução comentada de cadeias de significantes, hipotipose e dialeto. 365 p. Tese (doutorado) - Universidade Federal de Santa Catarina, Centro de Comunicação e Expressão. Programa de Pós-Graduação em Estudos da Tradução, 2011.

SHAW, Scott. Marguerite Duras and Charles Bukowski: The yin and yang of twentieth century erotica literature. (A Thesis presented in partial fulfillment of the requirements for the degree of Master of Arts in humanities). Faculty of California State University, Dominguez Hills, 1997.

WALSH, Vincent. Charles Bukowski: Maverick, Misfit, and Anomaly. Lehigh University, 2008.

WELLEK, René; WARREN Austin. Theory of Literature. New York: Harcourt, Brace and Company, 1949.

\footnotetext{
' Luana FERREIRA DE FREITAS, Profa.Dra.

Universidade Federal do Ceará (UFC)

luanafreitas.luana@gmail.com
}

\section{ii Rebecca de LIMA CORREIA}

Universidade Federal do Ceará (UFC)

rebecca.correia@yahoo.com.br 